\title{
Gamma Ray Spectrometry Analytical Determination of Radiation Levels in Bitumen Deposit Areas of Agbabu and Environment
}

\author{
Afolabi OM ${ }^{1 *}$, Aboluwoye $\mathrm{CO}^{2}$ and Ajayi IR ${ }^{1}$ \\ ${ }^{1}$ Physics and Electronics Department, Adekunle Ajasin University, Akungba Akoko Ondo state, Nigeria \\ ${ }^{2}$ Department of Chemical Sciences, Adekunle Ajasin University, Akungba Akoko Ondo state, Nigeria
}

\begin{abstract}
Twelve soil samples were collected near Bitumen intrusions in Agbabu and its adjoining environments and were analyzed with HPGe detector Gamma ray spectrometer and counted with comparative method. It was found that K- 40 , U-238, Th-232 concentrations in the soil range from $370.46 \pm 4.5-887.18 \pm 6.91, \times 8.14 \pm 5.49-71.35 \pm 21.92$ and $17.48 \pm 2.18-124.36 \pm 30.44 \mathrm{~Bq} / \mathrm{kg}$ respectively. The highest radioactivity in this research work is higher than former value of $165.64 \pm 2.91$. The highest concentration of K-40 in all the samples occurring close to the Oluwa river is $887.18 \pm 6.91 \mathrm{~Bq} / \mathrm{kg}$, which location also coincide with the place of highest sample concentration of Th-232 124.36 $\pm 30.44 \mathrm{~Bq} / \mathrm{kg}$. The area of large concentration of K-40 and Th-232 does not coincide with that of U-238, The average concentration of $40 \mathrm{~K}$ in all the analyzed samples is $640.72 \pm 5.42 \mathrm{~Bq} / \mathrm{kg}$ very high compared to the undetectable level formally reported and generally the radionuclide concentration values obtained have increased than the data in the former analysis done in the area. The highest U-238 concentration value of $71.35 \mathrm{~Bq} / \mathrm{kg}$ is higher than worldwide $40 \mathrm{~Bq} /$ $\mathrm{kg}$ average and it occurs around $1.2 \mathrm{~km}$ after Agbabu town close to the road $50 \mathrm{~m}$ from a bitumen outcrop. The absorbed dose rates $1 \mathrm{~m}$ in air have the highest value of $134.77 \mathrm{nG} / \mathrm{h}$. This is more than 3 times the worldwide average value 43 $\mathrm{nG} / \mathrm{h}$ for the soil sample collected close to the Oluwa River. The calculated absorbed dose rate in air range from 38.24$134.77 \mathrm{nG} / \mathrm{h}$. while the Annual effective absorbed dose is also highest with a value $165.39 \mu \mathrm{Sv} / \mathrm{y}$ close to river Oluwa (at GPS location N6 35,24.7 E4050I10.5) 9 times lower than the effective annual dose value of $1 \mathrm{mSv} / \mathrm{y}$ permitted for public exposure. The maximum external hazardous index value of 0.81 is less than the unity (1) permitted in ICRP 2000. Mining locations are suggested at other areas of bitumen outcrop with near surface soil that has lower than worldwide average concentration of radioisotopes and away from dwelling places and rivers where transport of mining tailings can increase accumulation of radionuclides in aquatic animals and local inhabitants.
\end{abstract}

Keywords: Gamma-ray analyzes; Samples; Bitumen; Radioisotopes; Location; Concentration

\section{Introduction}

Radiations are broadly categorized into ionizing and non-ionizing radiations, the ionizing radiation can be either direct or indirect ionizing radiation. These have enough energy to remove tightly bound electrons from atoms to create ions either directly or eventually. They are the X-ray, beta, alpha, neutron and gamma radiation. The nonionizing radiation have energy to move around atoms and make them just to vibrate but their energy levels are not enough to remove electron from atom, the non-ionizing radiation include visible light, ultraviolet, and microwaves including radiofrequency waves. The measurement of ionizing gamma radiation levels in mineral deposits is important due to the fact that almost all radiations eventually emit gamma radiation in their course of activities and determination of gamma radiation can eventually quantify the level of radiation present in mineral deposits including deposit of bitumen. Bitumen is useful for making or repairing roads, sheets of bitumen saturated felt are laid onto a flat roof with layers of bitumen below, between and above them for adequate heat insulation in buildings. In more complex roofing projects, bitumen is found holding in place a protective coating of chippings on the cantilevered roof of a sports stadium. Bitumen is also used in damp proofing and floor composition tiles, solidifying radioactive and other hazardous wastes before disposal. Other materials like felts and papers are impregnated with bitumen to improve their performance as regards insulation. Packaging papers, printing inks, linoleum, sound deadening felts hidden inside car bodies and the under sealing compounds, putty, plastic, cements, plumbing pipes, ebonized timber, air-drying and insulating paints, varnishes, electrical insulating compounds and battery boxes are some of the hundreds of industrial and domestic products that mostly contain bitumen. In agriculture bitumen is used in disinfectants, mulching, tree paintings, dam lining and dam protection etc. These various uses of bitumen indicate that soil background radiation levels in bitumen ore area must be known to protect and find better approach of reducing the contamination risk by making available radioactivity data for selection of appropriate mining sites and also to prevent and reduce radioactive contaminations (during or after mining) for the people who dwell in the deposit area, mine, use the mineral for manufacturing and those that will eventually come in contact with the products made from the bitumen deposit. Researches done on bitumen radionuclide concentrations are either generalized with very few samples either at a deposit without detail multi sampling of each Bitumen outcrop location despite the fact that radioactivity is a matter of spatial distribution as environment are not homogeneous [1]. These may be due to inadequate research funding and too few available radiation spectrometry equipment. Quantitative measurements of radioactive contamination in the bitumen field are difficult to accomplish properly as radiating particles having short ranges, such as alpha and low-energy beta radiation, are significantly and incalculably affected by minute amounts of overburden. Therefore, detection rather

*Corresponding author: Afolabi OM, Physics and Electronics Department Adekunle Ajasin University, Akungba Akoko Ondo state, Nigeria, Tel: 2347037529090; E-mail: afolabi100@gmail.com

Received Decemebr 26, 2013; Accepted January 28, 2014; Published January 31,2014

Citation: Afolabi OM, Aboluwoye CO, Ajayi IR (2014) Gamma Ray Spectrometry Analytical Determination of Radiation Levels in Bitumen Deposit Areas of Agbabu and Environment. J Environ Anal Toxicol 4: 211. doi: 10.4172/2161-0525.1000211

Copyright: (c) 2014 Afolabi OM, et al. This is an open-access article distributed under the terms of the Creative Commons Attribution License, which permits unrestricted use, distribution, and reproduction in any medium, provided the original author and source are credited. 
than site measurement is a more realistic goal for alpha-beta surveys. More penetrating radiations, such as gamma and higher energy X-rays, are affected less by overburden; however, quantification of isotopes through photon emissions requires isotopic-and geometry-specific response functions and focused laboratory measurement produces better radionuclide data from samples. There are two main parts of a radiation detection system, namely; the detector and the electronic instrumentation. Many detectors have been designed to measure radiation energy deposited in any medium. These include scintillation detector, for example, sodium iodide activated with thallium $(\mathrm{Na}(\mathrm{Tl}))$, gas filled detectors (ionization chambers, proportional counters and Geiger-Muller (GM) counters) and semiconductor detectors (pure silicon ( $\mathrm{Si}$ ), high purity Germanium HPGe), lithium-drifter germanium $(\mathrm{Ge}(\mathrm{Li})))$ as well as others such as cloud chambers, nuclear-track detectors and Cerenkov counters [2]. In gamma ray spectrometer; scintillation, gas proportional and semiconductor detectors are commonly used. Semiconductor detectors have the highest energy resolution, fast rise time of output pulse, superior noise to signal ratio and possibilities of variation of depth, area and geometry to improve sensitivity for various applications [3]. Gamma-ray spectrometry quantitatively studies the energy spectra of gamma-ray sources in Nuclear, Geophysical, Geochemical and other radiation measuring laboratories. Uranium, Potassium and Thorium have naturally occurring and abundant radioactive isotopes with decay series that produce sufficient gamma ray energies that are measureable with gamma ray spectrometers among all other naturally radioisotopes. ${ }^{40} \mathrm{~K}$ (with half life $1.3 \times 10^{9}$ years) is the radioactive isotope of potassium and occurs 0.012 percent of natural potassium, it decays to $40 \mathrm{Ar}$ with the emission of gamma rays with energy $1.46 \mathrm{MeV}$. Since ${ }^{40} \mathrm{~K}$ occurs as a known proportion of potassium element, it can be used to evaluate the total potassium present in the analyzed samples. Uranium occurs naturally as the radioisotopes ${ }^{238} \mathrm{U}$ and ${ }^{235} \mathrm{U}$ which give rise to decay series that terminate in stable isotopes ${ }^{206} \mathrm{~Pb}$ (half life $4.46 \times 10^{9}$ years) and ${ }^{207} \mathrm{~Pb}\left(7.13 \mathrm{x}^{8}\right.$ years $)$ respectively after the leads have emitted gamma rays. Thorium occurs naturally as the radioisotope ${ }^{232} \mathrm{Th}$ (half life $1.39 \times 10^{10}$ years) which gives rise to a decay series that terminates in the stable isotope ${ }^{228} \mathrm{Ac}$ after the Actinium has emitted gamma rays. Adebiyi et al. [4], in Multi-elemental analysis of Nigerian Bitumen by TXRF spectrometer mentioned that some Nigerian oil sands contain twelve elements: $\mathrm{K}, \mathrm{Ca}, \mathrm{Ti}, \mathrm{V}, \mathrm{Cr}, \mathrm{Mn}, \mathrm{As}, \mathrm{Fe}, \mathrm{Ni}, \mathrm{Cu}, \mathrm{Zn}$ and $\mathrm{Pb}$. The presence of $\mathrm{K}$ and $\mathrm{Pb}$ in the analysis done by Adebiyi et al. [4], shows that radioactive isotopes may be present in the oil sands even though no Ac was included in their elemental analysis. Gamma spectrometry and energy dispersive X-ray fluorescence were used to determine the presence and level of radioactivity of radionuclides in bituminous sand and overdurden obtained from bituminous sand deposits in Ondo state Nigeria for the purpose of providing baseline data and assessing its impact on the environment in 2003 [5]. The average specific activity concentration values they obtained for ${ }^{214} \mathrm{Bi}, 208 \mathrm{Tl}$, and ${ }^{226} \mathrm{Ra}$ in the overburden were $165.64 \pm 2.91,150.25 \pm 2.91$ and $60.97 \pm 2.27 \mathrm{~Bq}$ $\mathrm{kg}^{-1}$ respectively while then $40 \mathrm{~K}$ was found to be below the limit of detection. The measured activity in the bituminous sand layer was so low that it can be said to be non-radioactive. The result of the EDXRF supports the presence of radioelements in the overburden, which are likely to be embedded in accessory minerals like zircon and tourmaline. They stated that, the level of radioelements and associated decay daughter ${ }^{222} \mathrm{Rn}$ is not expected to cause any health hazard. Jibiri and Emelue [6] measured radioactivity using gamma-ray spectroscopy to determine the radionuclide concentrations in soil samples in the Warri Refining and Petrochemical Company and communities around it located in Delta state, Nigeria with sedimentary rock like that of the
Bitumen deposit of Ondo state. The $40 \mathrm{~K}$ activity concentration in their sedimentary soil samples analyzes range from $261.3-932.3 \mathrm{~Bq} / \mathrm{kg}$. Further research is therefore important to know the trend of radioactivity due to time and increased human activity or land use like deforestation, farming practices and other activities in the various bitumen deposit locations. In radio assay of the established fossil fuels found in Nigeria by Mokobia et al. [7] using a combination of gamma and total reflection X-ray fluorescence (TXRF) spectrometry, they indicated that of the three fossils, bitumen has a highest total of $61.54 \pm$ $23.93 \mathrm{~Bq} \mathrm{~kg}^{-1}$ followed by coal with a total of $30.48 \pm 5.29 \mathrm{~Bq} \mathrm{~kg}^{-1}$ while the least natural radioactivity $0.06 \pm 0.025 \mathrm{~Bq} \mathrm{~kg}^{-1}$ was found in the crude oil samples. Of the three fossil fuels, coal displayed the highest potential of containing most of the elements analyzed for while bitumen and crude oil indicate As, $\mathrm{Ca}, \mathrm{Cr}, \mathrm{Fe}, \mathrm{K}, \mathrm{Mn}, \mathrm{Ti}, \mathrm{V}$ and $\mathrm{Cr}, \mathrm{Fe}, \mathrm{Mn}$ and $\mathrm{V}$, respectively, at detectable levels. Most of these elements they analyzed for except As, Co, Cr and V are crustal or lithophilic and are found in coal and bitumen samples. They stated that the elements $\mathrm{Ni}, \mathrm{Cu}, \mathrm{Zn}, \mathrm{Pb}$ and $\mathrm{S}$ are fingerprint elements for crude oil and bitumen samples. Since bitumen have the tendency to be the most radioactive of the available fossil fuels, it is important to research on various bitumen deposits and their respective soils in adequately specified locations so as to know the spread of radioactivity due to different bitumen locations and the respective extractive methods that should be adhered to for protection of ecology. Gamma-ray spectrometer used in this research includes an energy sensitive radiation detector, electronics to collect and process the signals produced by the high purity-germanium detector (a passive semiconductor material waiting for gamma emission to occur in the detector volume) (Figure 1). The photoelectric effect that is proportional to all of the energy of the gamma ray emitted is employed in the semiconductor detector. The voltage pulses produced by the detector were shaped by analogue to digital converter and multichannel analyzer (MCA) into Gaussian or trapezoidal shape digital signal and were sort out by their heights. The ADC has specific channels in the spectrum where the signals are sorted.

These channels (whose typical values consist of 512, 1024, 2048, 4096, 8192 and 16384 channels) depending on the resolution of the system and the energy range being studied can be improved by modifying the software, amplifier and ADC hardware. The ADC output is stored, analyzed and displayed with software that contain spectrum analyzes tools such as energy calibration, MCA, peak area and net area and resolution calculation in the computer.

\section{Material and Methods}

The areas of sampling are located in Eastern Dahomey Sedimentary basin studied by Omatsola and Adegoke [8] whose sequence are subdivided into three stratigraphic units namely Ise formation, Alowo formation and Araromi formation based on the lithospheric study of some boreholes from the area. The Ise formation lying uncomfortably on the basement consists of alternating sands and clay units. The Alowo formation is bituminous and lies on the Ise formation. It consists of

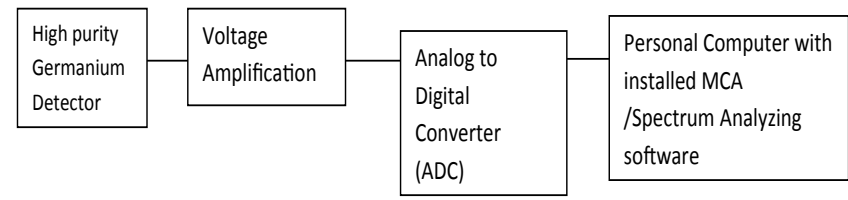

Figure 1: Electronic block diagram of Gamma-ray Spectrometry System. 
Citation: Afolabi OM, Aboluwoye CO, Ajayi IR (2014) Gamma Ray Spectrometry Analytical Determination of Radiation Levels in Bitumen Deposit Areas of Agbabu and Environment. J Environ Anal Toxicol 4: 211. doi: 10.4172/2161-0525.1000211

Page 3 of 4

alternating sands and shales units. The youngest Araromi formation is mostly marine shales, with thin limestone bands [8,9] and on the surface lie some sands, silt and humus or decaying organic matter intruded in many areas with black semi solid or liquid bitumen (this study). Bitumen deposits are found in Lagos, Ogun, Ondo and Edo states and Conoco's technical and economic evaluation indicated over thirteen billion barrels of oil are in tar sands and bitumen seepages.

Soil samples to be analyzed for radionuclide availability were collected inside polyethylene sack labeled distinctly to recognize areas of collection. The depths of sampling in the soil were at $15 \mathrm{~cm}$ depth in the vicinity of bitumen outcrops at Agbabu town, along the road away from the town including the neighboring villages along the road consisting of Ilubirin, Wilson Akinmulero Mile 2, Temidire, Ebute, Onisere and Olode Irele at $9 \mathrm{~km}$ from Ore Okitipupa road junction towards Irele town all in Ondo state, Nigeria. Table 1 shows the samples collected and their respective GPS locations. The soil samples were afterwards separated from each other to avoid cross contamination and spread on a suitable plastic sheet surface and allowed to dry at room temperature $25^{\circ} \mathrm{C}$ for 30 days. The samples were ground to a mesh size of $2 \mathrm{~mm}$. A semiconductor High-purity germanium (HPGe) detector mounted vertically and enclosed in a massive lead, coupled with PC based multichannel analyzer, Canberra model GC2018-7500 serial number b87063 and duly calibrated at the Centre for Energy and Development, Obafemi Awolowo University was used for the radionuclide count in $\mathrm{Bq} / \mathrm{Kg}$. Energy calibration was made by measuring mixed standard sources of known radionuclide with well-defined energy within the range $60 \mathrm{keV}$ to $3000 \mathrm{keV}$. Radiation damage that creates hole traps in semiconductor detector can degrade spectra resolution by diminishing the sensitivity of gamma ray detectors and line shape measurements. The Pulse shape discrimination (PSD) techniques were used in restoring the energy resolution and line shape for radiation damage in the detector. The low level gamma counting was carried out for 25,200s in order to get appreciate counts under the photo peaks. Two methods used in gamma counting are the Absolute Method and Comparative Method.

\section{Absolute method}

In this method, the specific radioactivity concentration $\mathrm{C}$ of a radionuclide which requires the variation of detection efficiency is given by

$$
C=\frac{A}{t E m P \gamma}(1)
$$

Where $\mathrm{A}$ is the net area of the peak, $\mathrm{t}$ is the time in seconds, $\mathrm{m}$ is the mass of the sample, $\mathrm{e}$ is the detection efficiency at the energy line and $\mathrm{P} \gamma$ is the gamma yield.

\section{Comparative method}

Here the specific activity of a radioisotope is obtained by direct comparison with the same radionuclide given in a standard by the equation

$$
C_{x}=\frac{C_{s} m_{s} A_{x}}{m_{x} A_{s}}
$$

Where $\mathrm{x}$ denotes the sample, $\mathrm{s}$ the standard, $\mathrm{m}$ the mass and $\mathrm{A}$ the net area under peaks respectively.

The Comparative method was used to determine the specific activity concentration of the bitumen soil samples hence the sample containers are of the same geometry and the counting time is equal to that of the standard.

\section{Results and Discussion}

It was found that K-40, U-238, Th-232 concentrations in the soil range from $370.46 \pm 4.5-887.18 \pm 6.91,8.14 \pm 5.49-71.35 \pm 21.92$ and $17.48 \pm 2.18-124.36 \pm 30.44 \mathrm{~Bq} / \mathrm{kg}$ respectively. The highest concentration of K-40 in all the samples occurring close to the Oluwa river is $887.18 \pm 6.91 \mathrm{~Bq} / \mathrm{kg}$, this sample location also coincide with the highest sample concentration of Th-232 $124.36 \pm 30.44 \mathrm{~Bq} / \mathrm{kg}$. The calculated average radioisotopes concentrations for all the samples are $612.17 \pm 5.32 \mathrm{~Bq} / \mathrm{kg}, 38.44 \pm 5.98 \mathrm{~Bq} / \mathrm{kg}$ and $79.85 \pm 20.95 \mathrm{~Bq} / \mathrm{kg}$ for $\mathrm{K}-40, \mathrm{U}-238$ and Th-232 respectively. The average concentration of $40 \mathrm{~K}$ is very high compared to the undetectable level reported by Fasasi et

\begin{tabular}{|c|c|c|c|c|c|c|c|}
\hline Samples & Soil Temperature & Relative humidity & Elevation & Location & $\mathrm{K}-40(\mathrm{~Bq} / \mathrm{kg})$ & U-238 (Bq/kg) & Th-232 (Bq/kg) \\
\hline SP1A & 37.1 & 11.4 & 12.1 & $\begin{array}{l}\mathrm{N} 6^{0} 35 ' 20.7 \\
\mathrm{E} 4^{0} 41^{\prime} 54.5\end{array}$ & $707.74 \pm 5.91$ & $38.81 \pm 3.73$ & $108.38 \pm 27.30$ \\
\hline SP1B & 35.2 & 10.8 & 10.0 & $\begin{array}{l}\mathrm{N} 6^{0} 35^{\prime} 24.0 \\
\mathrm{E} 4^{0} 49^{\prime} 58.6\end{array}$ & $715.61 \pm 6.06$ & $39.82 \pm 3.72$ & $118.42 \pm 29.05$ \\
\hline SP1C & 36.5 & 12.0 & 10.0 & $\begin{array}{l}\mathrm{N} 6^{0} 35^{\prime} 24.7 \\
\mathrm{E} 4^{0} 50^{\prime} 10.5\end{array}$ & $887.18 \pm 6.91$ & $49.04 \pm 4.34$ & $124.36 \pm 30.44$ \\
\hline SP1D & 34.4 & 14.0 & 13.1 & $\begin{array}{l}\mathrm{N} 6^{0} 35^{\prime} 24.3 \\
\mathrm{E} 4^{0} 49^{\prime} 56.9\end{array}$ & $444.66 \pm 4.50$ & $28.74 \pm 3.08$ & $117.53 \pm 29.05$ \\
\hline SP1E & 35.2 & 13.2 & 13.4 & $\begin{array}{l}\mathrm{N} 6^{0} 35^{\prime} 26.3 \\
\mathrm{E} 4^{0} 49^{\prime} 57.4\end{array}$ & $370.46 \pm 4.50$ & $71.35 \pm 21.92$ & $19.70 \pm 2.68$ \\
\hline SP1F & 35.7 & 13.4 & 13.6 & $\begin{array}{l}\mathrm{N} 6^{0} 35^{\prime} 26.9 \\
\mathrm{E} 4^{0} 49^{\prime} 58.6\end{array}$ & $504.04 \pm 4.18$ & $52.24 \pm 12.22$ & $52.47 \pm 3.63$ \\
\hline SP1G & 36.7 & 9.1 & 20.0 & $\begin{array}{l}\mathrm{N} 6^{0} 35^{\prime} 30.1 \\
\mathrm{E} 4^{0} 49^{\prime} 59.8\end{array}$ & $679.15 \pm 5.54$ & $28.70 \pm 3.06$ & $56.29 \pm 16.50$ \\
\hline SP1H & 36.3 & 11.2 & 16.0 & $\begin{array}{l}\mathrm{N} 6^{0} 35^{\prime} 32.4 \\
\mathrm{E} 4^{0} 49^{\prime} 59.7\end{array}$ & $857.15 \pm 6.60$ & $38.06 \pm 3.66$ & $101.37 \pm 25.74$ \\
\hline SP1I & 34.6 & 10.2 & 15.8 & $\begin{array}{l}\mathrm{N} 6^{0} 35^{\prime} 47.7 \\
\mathrm{E} 4^{0} 50^{\prime} 10.0\end{array}$ & $443.23 \pm 4.55$ & $17.74 \pm 2.46$ & $87.54 \pm 22.91$ \\
\hline SP1J & 34.7 & 10.7 & 6.3 & $\begin{array}{l}\mathrm{N} 6^{0} 35^{\prime} 55.7 \\
\mathrm{E} 4^{0} 50^{\prime} 00.5\end{array}$ & $516.15 \pm 4.71$ & $53.68 \pm 4.62$ & $67.98 \pm 19.34$ \\
\hline SP1K & 35.7 & 11.2 & 11.5 & $\begin{array}{l}\mathrm{N} 6^{0} 39^{\prime} 50.7 \\
\mathrm{E} 4^{0} 49^{\prime} 53.2\end{array}$ & $646.98 \pm 5.41$ & $35.01 \pm 3.49$ & $86.69 \pm 22.59$ \\
\hline SP1L & 35.8 & 11.3 & 11.4 & $\begin{array}{l}\mathrm{N} 6^{0} 39150.2 \\
\mathrm{E} 4^{0} 49^{\prime} 52.5\end{array}$ & $573.69 \pm 4.93$ & $8.14 \pm 5.49$ & $17.48 \pm 2.18$ \\
\hline
\end{tabular}
al. [5]. $238 \mathrm{U}, 40 \mathrm{~K}$ and $232 \mathrm{Th}$ highest concentrations are greater than

Table 1: Samples Location, Physical and Radioisotope Data. 
Citation: Afolabi OM, Aboluwoye CO, Ajayi IR (2014) Gamma Ray Spectrometry Analytical Determination of Radiation Levels in Bitumen Deposit Areas of Agbabu and Environment. J Environ Anal Toxicol 4: 211. doi: 10.4172/2161-0525.1000211

Page 4 of 4

the worldwide average $370 \mathrm{~Bq} / \mathrm{kg}$ for $\mathrm{K}-40$ and $40 \mathrm{~Bq} / \mathrm{kg}$ for $\mathrm{Th}-232$ respectively [10]. Mining of Bitumen is not suggested to be sited there due to fish and other aquatic animal that may ingest and accumulate radioactive wastes and large area transport of mining waste that may spread to where mining is not done. The area of large concentration of K-40 and Th-232 does not coincide with that of U-238, the highest $\mathrm{U}-238$ concentration value of $71.35 \mathrm{~Bq} / \mathrm{kg}$ higher than worldwide 40 $\mathrm{Bq} / \mathrm{kg}$ average occur around $1.2 \mathrm{~km}$ after Agbabu town close to the road $50 \mathrm{~m}$ from a bitumen outcrop. Mining locations are suggested at other areas with bitumen outcrop that has lower than worldwide average concentration of radioisotopes.

\section{Derivation of absorbed, annual effective doses and hazard indices}

For a uniformly distributed radionuclide, the absorbed dose $\mathrm{D}$ in a unit nGyh-1 can be calculated from the results obtained from the samples with the [11] equation

$$
D(a)=0.0417 C_{K}+0.462 C_{U}+0.604 C_{T h}\left(n G y h^{-1}\right)(3)
$$

Where $\mathrm{D}$ is the total absorbed dose rate in air, $\mathrm{C}_{\mathrm{K}}, \mathrm{C}_{\mathrm{U}}$ and $\mathrm{C}_{\mathrm{Th}}$ are the activity concentrations of ${ }^{40} \mathrm{~K},{ }^{238} \mathrm{U}$ and ${ }^{232} \mathrm{Th}$ respectively in $\mathrm{Bq} / \mathrm{kg}$.

The annual effective dose in unit of $\mathrm{mSv} / \mathrm{yr}$ was derived by converting the total absorbed dose in $\mathrm{nGy} / \mathrm{h}$ and multiplying by time $\mathrm{T}$ of one year using the equation

$$
D(e)=D\left(n G y h^{-1}\right) \times T\left(h r y^{-1}\right) \times F\left(\mu S v y^{-1}\right)(4)
$$

Where $\mathrm{D}$ is the calculated dose rate, $\mathrm{T}$ is time in hours for a year given for a factor of exposure 0.20 per day throughout the year in Agbabu and neighboring (that are rural area whose occupancy time calculated by Arogunjo and Adekola, [12] can range from 3.99-8.91 h) bitumen locations as $\mathrm{T}=0.20(24)(365+1 / 4) \mathrm{hry}-1$ (5) and $\mathrm{F}$ is the conversion factor given in UNSCEAR 2000 [10] as $0.7 \times 10^{-3} \mu \mathrm{Sv} / \mathrm{y}$.

Equation 3 to 5 was implemented in EXCEL spreadsheet with the concentrations of Table 1 for calculating absorbed and annual effective doses (Table 2). The external hazard index $\mathrm{H}$ was also calculated [11] with the equation

$$
H=\frac{1}{370} C_{U}+\frac{1}{259} C_{T h}+\frac{1}{4810} C_{K}(6)
$$

The absorbed dose rates $1 \mathrm{~m}$ in air have the highest value of $134.77 \mathrm{nG} / \mathrm{h}$. This is more than 3 times the worldwide average value 43 $\mathrm{nG} / \mathrm{h}[10,13]$ for the same sample SP1C collected close to the Oluwa river. The calculated absorbed dose rate in air range from 38.24-134.77 $\mathrm{nG} / \mathrm{h}$. The Annual effective absorbed dose is also highest with a value $165.39 \mu \mathrm{Sv} / \mathrm{y}$ close to river Oluwa sample point at $\mathrm{N} 6^{0} 35^{\mathrm{I}} 24.7 \mathrm{E} 4^{0} 50^{\mathrm{I}} 10.5$ but this is more than 9 times lower than the effective annual dose value of $1 \mathrm{mSv} / \mathrm{y}$ permitted for public exposure $[13,14]$. The maximum external hazardous index value of 0.81 is less than the unity (1) permitted in ICRP 2000. The range of annual effective dose is $46.93-165.39 \mu \mathrm{Sv} / \mathrm{y}$ while the external hazard index ranges from $0.211-0.81$. The average values of absorbed dose rate in air, annual effective absorbed dose and external hazard index are respectively $91.52 \mathrm{nG} / \mathrm{h}, 112.32 \mu \mathrm{Sv} / \mathrm{y}$ and 0.55 .

\section{Conclusion}

The gamma ray analysis done on 12 soil samples in some Bitumen deposit environment has shown that eleven of the samples have more than world average absorbed dose rates in air although all the areas have much lower than $1 \mathrm{mSv} / \mathrm{y}$ annual effective absorbed dose permitted by ICRP. The external hazard index for the area where soil samples were

\begin{tabular}{|c|c|c|c|c|c|c|}
\hline Samples & $\begin{array}{c}\mathbf{K}-\mathbf{4 0}(\mathbf{B q} / \\
\mathbf{k g})\end{array}$ & $\begin{array}{c}\mathbf{U}-238 \mathbf{( B q} / \\
\mathbf{k g})\end{array}$ & $\begin{array}{c}\text { Th-232 } \\
\mathbf{( B q} / \mathbf{k g})\end{array}$ & $\begin{array}{c}\text { Absorbed } \\
\mathbf{d o s e} \mathbf{r a t e} \\
\mathbf{n G / h}\end{array}$ & $\begin{array}{c}\text { Annual } \\
\text { effective } \\
\mathbf{d o s e} \mathbf{\mu S v / y}\end{array}$ & $\begin{array}{c}\text { External } \\
\text { hazard } \\
\text { index }\end{array}$ \\
\hline SP1A & 707.74 & 38.81 & 108.38 & 112.9045 & 138.5609 & 0.685551 \\
\hline SP1B & 715.61 & 39.82 & 118.42 & 119.7635 & 146.9785 & 0.730077 \\
\hline SP1C & 887.18 & 49.04 & 124.36 & 134.7653 & 165.3894 & 0.814425 \\
\hline SP1D & 444.66 & 28.74 & 117.53 & 102.8083 & 126.1705 & 0.640241 \\
\hline SP1E & 370.46 & 71.35 & 19.7 & 60.31068 & 74.01568 & 0.348657 \\
\hline SP1F & 504.04 & 52.24 & 52.47 & 76.84523 & 94.30754 & 0.455859 \\
\hline SP1G & 679.15 & 28.7 & 56.29 & 75.57912 & 92.75371 & 0.443923 \\
\hline SP1H & 857.15 & 38.06 & 101.37 & 114.5544 & 140.5857 & 0.686547 \\
\hline SP1I & 443.23 & 17.74 & 87.54 & 79.55273 & 97.63029 & 0.490254 \\
\hline SP1J & 516.15 & 53.68 & 67.98 & 87.38354 & 107.2406 & 0.524309 \\
\hline SP1K & 646.98 & 35.01 & 86.69 & 95.51445 & 117.2191 & 0.575889 \\
\hline SP1L & 573.69 & 8.14 & 17.48 & 38.24147 & 46.93147 & 0.21119 \\
\hline
\end{tabular}

Table 2: Gamma-ray absorbed dose, Annual Effective dose and External Hazard index in Agbabu Environment.

collected was less than the unity permitted by ICRP. It is therefore suggested that areas close to river and dwelling area should not be mined for bitumen to reduce the eventual accumulation of radionuclide in aquatic and terrestrial lives.

\section{References}

1. Ademola JA, Ademonehin S (2010) Radioactivity concentrations and dose assessment for bitumen and soil samples around a bituminous deposit in Ondo state, Nigeria. Radioprotection 45: 359-368.

2. Cherry SR, Sorenson JA, Phelps ME (1980) Physics in Nuclear Medicine, Grune \& Stratton, New York, USA.

3. Knoll GF (2010) Radiation detection and Measurements. (4th edn), John Wiley and Sons, New York, USA.

4. Adebiyi FM, Asubiojo OI, Ajayi FR (2006) Multi-elemental analysis of Nigerian Bitumen by TXRF spectrometry and the physical constants characterization of its hydrocarbon component. Fuel 85: 396-400.

5. Fasasi MK, Oyawale AA, Mokobia CE, Tchokossa P, Ajayi TR, et al. (2003) Natural radioactivity of the tar-sand deposits of Ondo State, Southwestern Nigeria. Nuclear Instruments and Methods in Physics Research Section A: 505: 449-453.

6. Jibiri NN, Emelue HU (2008) Soil radionuclide concentrations and radiological assessment in and around a refining and petrochemical company in Warri, Niger Delta, Nigeria. J Radiol Prot 28: 361-368.

7. Mokobia CE, Adebiyi FM, Akpan I, Olise FS, Tchokossa P (2006) Radioassay of prominent Nigerian fossil fuels using gamma and TXRF spectroscopy. Elsevier, Fuel. 85: 1811-1814

8. Omotsola ME, Adegoke OS (1981) Techtonic Evolution and Cretaceous Stratigraphy of Dahomey Basin. Nigeria J Min Geol 1: 44-48.

9. Odunaike RK, Laoye JA, Fasuwon OO, ljeoma GC, Akinyemi EP (2010) Geophysical mapping of the Occurrence of shallow oil sands in Idiopopo at Okitipupa area, South-western Nigeria. African Journal of environmental Science and Technology 4: 034-044.

10. United Nations Scientific Committee on the Effects of Atomic Radiation UNSCEAR (2000) Sources, effects and risks of ionization radiation. Report to The General Assembly, Annexes B: Exposures from Natural Radiation Sources. New York: UNSCEAR.

11. Senthilkumar B, Dhavamani V, Ramkumar S, Philominathan P (2010) Measurement of gamma radiation levels in soil samples from Thanjavur using gamma-ray spectrometry and estimation of population exposure. J Med Phys 35: $48-53$.

12. Arogunjo AM, Adekola AS (2007) Occupancy factor Model for Exposure to Atmospheric Radiation by Urban and Rural Dwellers in Nigeria. Journal of Applied Sciences 7: 1343-1346

13. Kinyua R, Atamiro VO, Ongeri RM (2011) Activity concentrations of 40K, 232Th 226Ra and radiation exposure levels in the Tabaka soapstone quarries of the Kisii Region, Kenya. African Journal of Environmental Science and Technology 5: 682-688.

14. International Commission on Radiological Protection, ICRP (2000) Annua Report. 